\title{
The Influence of Personal and Psychological Factors toward Consumer Purchase Decision (Case Study: PETERSAYSDENIM, Bandung)
}

\author{
Vici Fitrayanti, Purwanto \\ Management Study Program, Faculty of Business, President University \\ Email: Vici.fitrayanti@gmail.com, purwanto@president.ac.id
}

Received: August $25^{\text {th }} 2020$

Approved: September $19^{\text {th }} 2020$

\begin{abstract}
The purpose of this research is to analyze the influence of personal and psychological factors toward consumer purchase decision of PeterSaysDenim in Bandung. Those factors are important to the company because it would influence in consumer purchase decision on company's product. This research uses quantitative analysis with has six independent variables (motivation, belief and attitudes, occupation, economic situation, personality and self-concept, and lifestyle) and one dependent variable (purchase decision). The analysis method that is used in this research is multiple linear regressions. The result shows that, there are partial significant influence of motivation, personality and self-concept, and lifestyle, and no partial significant influence toward consumer purchase decision. There is simultaneous significant influence of motivation, belief and attitudes, occupation, economic situation, personality and self-concept, and lifestyle toward consumer purchase decision with adjusted $\mathrm{R}$ square is $47.8 \%$. The most significance value from all independent variables toward dependent variable is lifestyle.
\end{abstract}

Keywords: Personal Factor, Psychological Factor, Purchase Decision, Consumer Behavior, PeterSaysDenim

\section{INTRODUCTION}

Creative Industry is potential business and becomes the first choice field of industry for youngster who wants to be enterpreneur. Creative industry sues an entrepreneur to be creative by skills and knowledge. According to Badan Pusat Statistik, in 2013 Indonesian GDP (Gross Domestic Product) was Rp. 9,109,129.4 Billion and Creative industry was in ranked $7^{\text {th }}$ with Rp. 641,815.4 Billion. In 2012, GDP was Rp. 8,241,864.3 Billion and creative industry was Rp. 578.760.6 Billion.

Since $20^{\text {th }}$ century, fashion becomes one of the main necessary of human being and as the personality picture of the person who wearing it. Actually, fashion is changing every year based on the theme while the theme comes from inspiration, social trend, economic conditions, icon cultural and musician trend style. There are the kinds of fashion items such as pants, skirts, clothes, dress, bags, footwear, watch, hat and accessories. The increasing of 
Indonesian fashion industry and consumer awareness makes consumer been selective in choosing fashion item. It is been challenging to the fashion industry to be more creative to compete with others competitor either local or import brand and many new fashion designer was coming that offers new ideas, concept and more fashionable to create their own designs and styles (character), with their own brand. Fashion divided by 4 segments that are:

1. Local brand (PeterSaysDenim, Tomkins, Lea, Buccheri, etc)

2. Foreign designer / Import brand (Zara, Pull \& Bear, H\&M, C\&K, etc)

3. Local fashion designer, (Adjie Notonegoro \& Poppy Dharsono)

4. Fashion temporary for special event like wedding (Anne Avantee and Fery Sunarto). The highest demand is daily outfit such as jeans, T-shirt, jackets, sneaker, and sandal. Therefore, many young entrepreneurs refer to choose daily outfit as the fashion business.

Indonesia is the fourth biggest population country in the world which has potential market for world fashion industry. Therefore, many foreign companies compete to entrance Indonesian market, proven by many import brands that we can find in Mall, ITC and department store while local brand difficult to compete with the other import brands because of the quality and price. Actually, local brand is not so difficult to get local market as long as there is will and has skill. Fashion business sues designer to be creative to create the design because the design changed so quickly. Since 3 years ago, Indonesian government has concerned with the development of small- and medium-scale enterprises (SMEs) because SMEs as safer when Indonesia got crisis because SME are more flexible and quickly of decision making and it's also absorb a lot of employee.

In 2000's, there are so many home industries or local brand springing up and compete with the famous import brand. For example, Peter Says Denim or PSD is one of local brand that has been famous in denim industry. Since 2008, Peter Firmansyah as the owner was created the brand with the strong character and quality as priority makes Peter becomes one of inspiring young entrepreneur because his brilliant idea that create pants with denim material. By the hobby, he created PSD that combine fashion and music. He likes music, and as the personnel and founder of Peter Says Sorry, the idea was came from when Peter and his band performed, he wants to be cool and fashionable while there were no jeans with new design in the market, the design was same from all the brands and material.

Peter Says Denim is one of local brands based in Bandung and become pioneer of denim Indonesia with prestigious of brand image that offer uniqueness and has strong character than the others local brands. Proven by Peter Says Denim belong favorite denim of American musician likes Of Mice Man, We Shot The Moon, and Before Their Eyes, I am Committing A Sin, and Silverstein. These bands are wearing Peter Says Denim when they were during tour. Peter Firmansyah has a dream to achieve global market with strategy by opened representative office and store in Canada. Whereas, ASEAN, Japan, Australia and other European country were just selling for online only and sometimes PSD opens stand on exhibition in tour of the bands that have been cooperated. Peter focus to break European and American market. He thought that when the brand has marketed in European and American market it means that its brand has been real world market.

Peter Firmansyah was looking for the best material to compete with other big brand over the world and every design inspired by Old-Skool style of legend band from America and Canada with simple and practical design. Peter Says Denim opens the official store in JL. Ciumbeluit no 109 Bandung, while consumer from outside of Bandung, Peter Says Denim serves the consumer by the online with the purpose get the profit wherever for consumer in everywhere and also received for reseller who having store as the special store of PSD. Reseller was taking the product with minimum order Rp.20,000,000 in cash payment and getting discount up to 30\%. From 2009 - 2013, Peter Says Denim is still leading Indonesian 
denim market with youngster as the high demand. Unfortunately, when 2011 to 2012 the market was went down because of world crises, it's automatically makes consumer to limit their consumption (Firmansyah, 2014).

Peter Firmansyah as the founder of PSD was represented by his interest in skateboarding, music (rock and metal) and graphic design. Consumer starts to purchase the product based on their behavior and it's automatically will related to their needs and wants, so company should be focused on the consumer behavior. In this case, most of the consumer of PSD is people who don't like about skateboarding, music (rock and metal), and graphic design but there are many brands that offer other characters in the market. It means that, PSD is a denim brand that can be accepted by everyone. Below is the comparison design between PSD with other local brands. So, this research is to find out personal and psychological factors that influence consumer purchase decision and used six independent variables: motivation, belief and attitudes, occupation, economic situation, personality and self-concept, and lifestyle.

\section{LITERATURE REVIEW AND HYPOTHESIS}

Age and life-cycle stage is helpful for the marketer to identify the stage or target market of the product. Over time, consumers change goods and services. The family life cycle includes several processes, namely young singles, married couples, unmarried couples, and others (Shah A., 1998).

Doing work, games or activities of daily life in worldly, physical, and socio-cultural contexts that are characteristic as references in occupation (Kielhofter, 2002). Occupation is single indicator of person's social class because of it so highly correlates with the most of the other dimension notably education and income, so it's the most widely used single-item index in consumer research on social class (Lantos, 2011). Occupation also shapes the pattern of consumer behavior. People belonging to different occupations behave in a different manner in many aspects, so the marketers design different product to cater to the needs of different occupational groups (Trehan, 2006). In this research, occupation is independent variable of influence consumer purchase decision because occupation can determine the fashion style of people and human condition that can identify the level of consumption which every occupation has different requirement.

The economic situation has a major impact on consumer purchasing decisions where people with high economic levels have high purchasing power. The economic situation will influence product choice and trend marketers watching income-sensitive goods in personal income, savings, and interest rates (Gianie Abdu and Purwanto, 2013). A society that has a high economic level means that people have many alternatives to choose and get good quality products without having to look for prices. According to Richard (2014), Products that are more expensive will be able to be purchased by consumers who have a lot of income and have a lot of savings, on the other hand, people whose income and savings are small will be able to buy cheap goods. So, the economic situation is used as this study which serves as an independent variable to influence PeterSaysDenim's consumer purchasing decisions.

Lifestyle has a relationship between the products offered in the market and the lifestyle desired in the group (Mathin Khan, 2006). Lifestyle indicates how people live and describe themselves based on their activities, interests and opinions as well as how to express them and can measure behavior in purchasing decisions.

Talks about personality, it means the characteristics of person that as a result of social and 
environment. Personality reflects individual differences and makes people become unique. Earlier studies in the domain of self-concept have conceptualized self-concept as a multidimensional construct (Hamm \& Cundiff, 1969) which enabled a consumer to evaluate himself in the context of various social situations. Self-concept refers to the beliefs a person holds about his or her attributes and how he or she evaluates these qualities and help determine the perceived self, and in some way 'we are what we have' (Belk, Russell W., 1988, pp. 139-168). Personality and self-concept is a basic for a marketer in fashion industry. Self-concept begins to get beyond just the considerations of physical characteristic include more abstract inner qualities and characteristic such as moral values, personal beliefs and ideologies. (Carducci, 2009).

There are many factors that influence of consumer behavior, but psychological factor is study about internal factor that shape consumer behavior. A person's buying choices are further influenced by four major psychological factors: motivation, perception, learning, belief and attitudes (Philiph Kotler \& Amstrong, 2008). In this research, motivation, and belief and attitudes are independent factor that influence consumer purchase decision of PeterSaysDenim.

Trying to understand purchase decision is very challenging. Sometimes, consumer says one thing but do another. According to (Kotler and Amstrong, 2001, p. 226), consumer decision is a step in the consumer purchase decision-making process in which consumers actually buy. In the process of purchase decision, consumer is not always following these 5 stages. It depends on the product such as newspaper is do not involve lengthy search or evaluation activities and complex purchase like home is often lengthy because they incorporate every stage of purchasing process (Ferrell \& Hartline, 2008).

In this research, the theoretical framework were built as a guide for researcher to develop the thesis with the right flow, the researcher will use motivation, Belief and Attitudes, economic situation, occupation, personality and self-concept and lifestyle as independent variable to determine the consumer behavior which becomes the dependent variable on this survey.

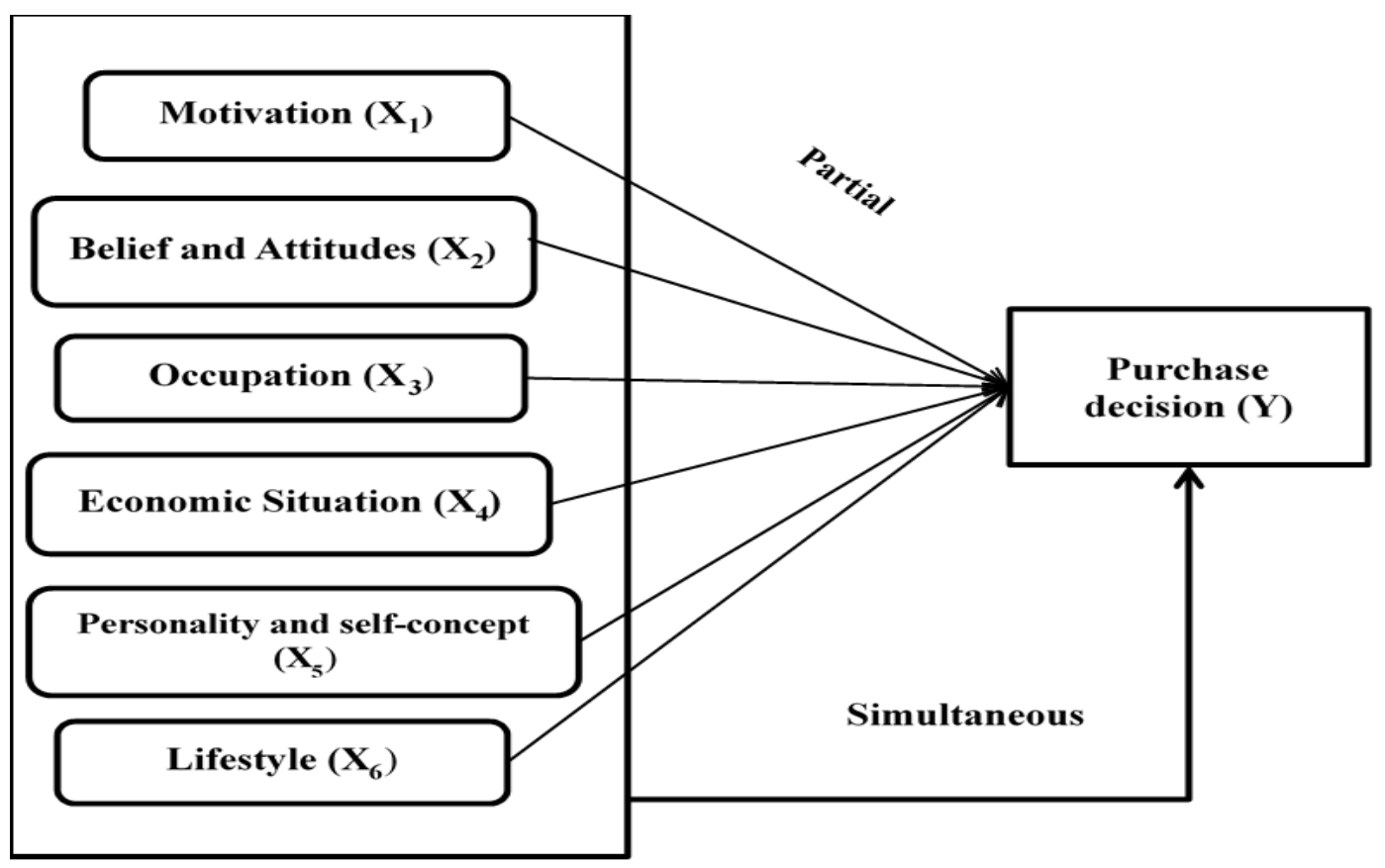

Figure 2. Theoretical Framework

Source: Adjusted by Researcher, 2020 
Regarding the problem and theoretical framework above, the hypotheses are

$\boldsymbol{H}_{\boldsymbol{1}}$ : There is an influence of motivation toward consumer purchase decision

$\boldsymbol{H}_{2:}$ There is an influence of belief and attitudes toward consumer purchase decision

$\boldsymbol{H}_{3}$ : There is an influence of occupations toward consumer behavior

$\boldsymbol{H}_{4}$ : There is an influence of economic situation toward consumer behavior

$\boldsymbol{H}_{5}$ : There is an influence of personality and self-concept toward consumer behavior

$\boldsymbol{H}_{6}$ : There is an influence of lifestyle toward consumer behavior

$\boldsymbol{H}_{7}$ : There is simultaneous influence of motivation, belief and attitudes, occupation, economic situation, personality and self-concept, and lifestyle toward consumer purchase decision

\section{METHODOLOGY}

This research conducted implanting a structured research design in the form of numbers and provides fundamental connection between empirical observation and mathematical expression of quantitative relationship. Different methodology has been used to attain the final result. From the description above, the research method that is suitable for this research is a quantitative research since this research is conducted to seek conclusive evidence which based on large samples and applies some form of statistical tools and also used quantitative research which rely secondary data as sources (journal). It is questionnaire will be as guide to analyze independent variable of factor analysis method to know the level of influence personal and psychological towards consumer purchase decision of PeterSaysDenim in Bandung.

World is large and full of people when we do research, we couldn't ask all the people in whole population. In this case, it is impossible to ask all of the consumers of PeterSaysDenim in Bandung. So, sample helps researcher to collects the data from the questionnaire without ask all of population. According to (Hasan, 2002) Sample is part of population that taken from the certain way, clear, and comprehensive as the representative of population. This research was used unknown population formula to determine the number of sample size because we couldn't know the number of population (consumer Peter Says Denim in Bandung). Below is the formula for unknown population:

$$
\begin{aligned}
\mathbf{n} & =\frac{Z \alpha^{2} \times \sigma}{\mathrm{e}^{2}} \\
\mathbf{n} & =\frac{1.96^{2} \times 0.25}{0.1^{2}} \\
& =97 \text { Respondents }
\end{aligned}
$$

According to Gay and Diehl (1992), that the sample size should be as big as possible, it means that more sample are taken will be more representative. So, in this research used 100 respondents for the sample size.

The questionnaire design consists of three sections, there are: introduction, respondent demographic and survey questions. The questionnaire constructed in English and Bahasa Indonesia because most of consumer is limited in English. Researcher spread the questionnaire by the paper and Google drive. Paper for the respondent in meet directly and Google Drive for the respondent who couldn't meet directly. Introduction section is section which explains about the short profile of researcher that related to the purpose by doing the research such as the questionnaire support the research as the requirement in fulfillment Bachelor Degree in Economic and the objective of research is Peter Says Denim. The second section is respondent demographic data. It consists of name, gender, age, level of education, 
monthly income and when respondent purchased PeterSaysDenim. The third section is questionnaires which consist of 29 statements that divided by 6 independent variables and 1 dependent variable that influence of purchase decision and this research used Likert scale.

Reliability test result used cronbach alpha formula. It will be reliable if the cronbach's alpha of each variable is above 0.60 . The result shows that all of variable are reliable because cronbach's alpha from all independents variable $>0.60$.

Table 1. Reliability test result

\begin{tabular}{|c|c|c|c|c|}
\hline No & Variable & $\begin{array}{c}\text { Cronbach } \\
\text { s Alpha }\end{array}$ & $\begin{array}{c}\text { Number of } \\
\text { Question Items }\end{array}$ & Reliability \\
\hline 1 & Motivation $\left(\mathrm{X}_{1}\right)$ & 0.890 & 5 & Reliable \\
\hline 2 & Belief and Attitudes $\left(\mathrm{X}_{2}\right)$ & 0.919 & 4 & Reliable \\
\hline 3 & Occupation $\left(\mathrm{X}_{3}\right)$ & 0.634 & 4 & Reliable \\
\hline 4 & Economic Situation $\left(\mathrm{X}_{4}\right)$ & 0.710 & 4 & Reliable \\
\hline 5 & Personality and self-concept $\left(\mathrm{X}_{5}\right)$ & 0.854 & 4 & Reliable \\
\hline 6 & Lifestyle $\left(\mathrm{X}_{6}\right)$ & 0.763 & 4 & Reliable \\
\hline 7 & Purchase Decision & 0.906 & 4 & Reliable \\
\hline \multicolumn{4}{|c|}{ Total statement } & 29 \\
\hline
\end{tabular}

Sources: Primary Data, 2020

Validity test is used to measure whether the questionnaire valid or not. When Rcompute $>$ Rtable means that the statement of questionnaire is valid. This research used SPSS 16.0 to determine the validity statement of questionnaire which Rtable is 0.361 from $\mathrm{df}=\mathrm{N}-2$ where $(\mathrm{n}=30)$ with significant level 0.05 . The Rcompute from all the statement of questionnaires is greatest than 0.361 , so all of the statements are valid.

Normality test is to determine the normality of distributed data in statistic. The normality of data can be determined by residual value. In this research, researcher use normal probability P- Plot by SPSS 16.0 to determine whether the data is normal distribution or not normal distribution. According to (Ghozali, 2011) if the assumption meet diagonal line (concentrated in the middle of curve) means that the data is normal distribution which the researcher is representative of population.

Multicolinearity is a linear correlation between independent variable in multiple regressions (Widarjono, 2010). Multicollinearity can be detected by covariance matrix determinant and using Variance Inflation Factors (VIF) and tolerance. If value of covariance matrix determinant is low, there is problem in multicolinearity. If VIF $<10$ and value of tolerance $>0.1$ means that there is non-multicolinearity. The number of VIF shows how much the variance of the coefficient being inflated by multicollinearity.

Autocorrelation test is to determine correlation between errors occurred in the (t-1) in regression model. According to (Ghozali, 2011) time series where there might occurs autocorrelation problem that interfere each other. Durbin-Watson significant table will be utilized as the parameter to measure autocorrelation of the data. There is no autocorrelation if the value of Durbin Watson is from 1.715 to 2.22848 .

Heteroscedasticity appear if independent variable significant influence residual of regression result. In heteroscedasticity test, we can see by the pattern of scatterplot, it is normal distributed or homoscedasticity when the points spread and not converge in one point. aIf the points are tendencies to make a pattern, its means the data are not normal distributed and considered to become heteroscedasticity. Based on Yustisia (2008) the way to detect 
heteroscedasticity is by look up graph plot between dependent variable (ZRESID) and independent variable (ZPRED).

In this research, researcher used multiple any regression model, there is an implicit assumption (which can be tested) that a relationship exist between the variables. There is also some random error that cannot be predicted. In this research will analyze and examine the variables that affect the purchasing decision. Since the research will analyze and examine more than 2 independent variables on the dependent variable, hypothesis testing is using multiple regressions.

$$
Y=\beta_{0}+\beta_{1} X_{1}+\beta_{2} X_{2}+\beta_{3} X_{3}+\beta_{4} X_{4}+\beta_{5} X_{5}+\beta_{6} X_{6}+\varepsilon
$$

where $Y=$ purchase decision, $\beta_{0}=$ constant, $\beta_{1}, \beta_{2}, \ldots, \beta_{6}=$ regression coefficient, $\mathrm{X}_{1}=$ motivation, $\mathrm{X}_{2}=$ belief and attitudes, $\mathrm{X}_{3}=$ occupation, $\mathrm{X}_{4}=$ economic situation, $\mathrm{X}_{5}=$ personality and self-concept, $\mathrm{X}_{6}=$ lifestyle, and $\varepsilon=$ error.

\section{Results and Discussion}

\section{Descriptive Statistic}

In this section, researcher makes a descriptive analysis by descriptive statistic output above. There are 6 independent variables and one dependent variable which have mean and standard deviation results.

Table 2. Descriptive Statistics

\begin{tabular}{|c|c|c|c|}
\hline & Mean & Std. Deviation & $\mathrm{N}$ \\
\hline PurchaseDecision & 3.695 & 2.04781 & 100 \\
Motivation & 3.680 & 2.68930 & 100 \\
BeliefandAttitudes & 3.685 & 2.06764 & 100 \\
Occupation & 3.4375 & 2.28908 & 100 \\
EconomicSituation & 3.555 & 2.10617 & 100 \\
Personality & 3.4475 & 2.09518 & 100 \\
Lifestyle & 3.5275 & 2.18764 & 100 \\
\hline
\end{tabular}

\section{Normality}

Normality test is the first kind of test to determine whether a data set is a normal distribution or not. In this research using parametric statistical and the purpose is to know does questionnaires were requirement parametric or not. The data has normal distribution means the data can be representative of population. Researcher uses histogram and P-P plot. Below is the histogram normality test. 


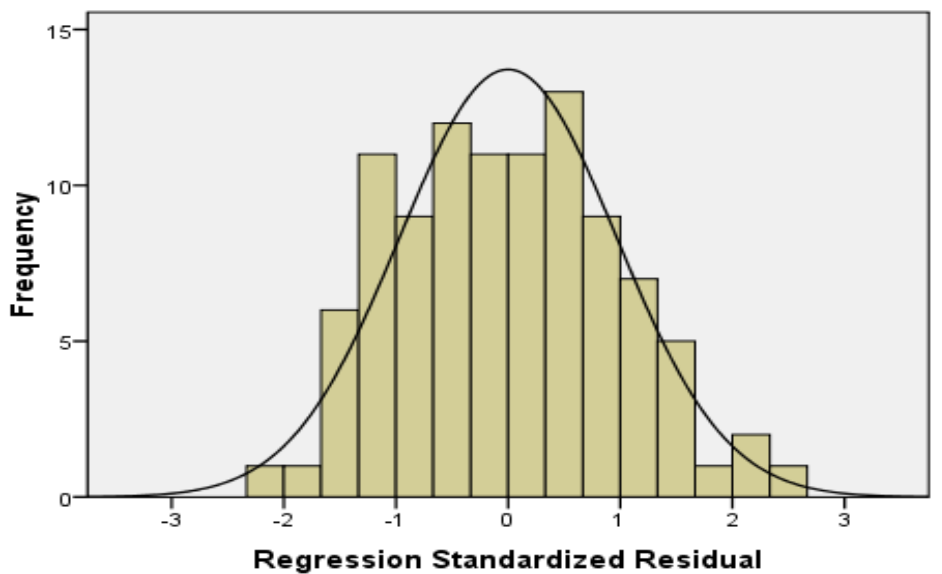

Figure 1. Histogram

\section{Multicollinearity}

Multicolinearity is linear correlations among the independent variables are strong in multiple regression VIF measures how much the variance of the estimated coefficients is increased over the case of no correlation among the $\mathrm{X}$ variables. If VIF $<10$ and value of tolerance $>0.1$ means that there is non-multicolinearity. The number of VIF shows how much the variance of the coefficient being inflated by multicollinearity. Based on the table 3 Multicolinearity test, all of independents variable has VIF $<3$ means that there is no multicollinearity and the value of tolerance from all variables $>0.1$ means that also there is no multicollineaity. The result of multicollinearity test can see as follow:

\section{Table 3. Multicolinearity Test}

\begin{tabular}{|c|c|c|}
\hline \multirow{2}{*}{ Coefficients $^{\mathbf{a}}$} & \multicolumn{2}{|c|}{ Collinearity Statistics } \\
\cline { 2 - 3 } Model & Tolerance & VIF \\
\hline (Constant) & & \\
Motivation & .595 & 1.680 \\
BeliefandAttitudes & .640 & 1.564 \\
Occupation & .413 & 2.420 \\
EconomicSituation & .440 & 2.274 \\
Personality & .364 & 2.745 \\
Lifestyle & .501 & 1.997 \\
\hline
\end{tabular}

a. Dependent Variable: PurchaseDecision

\section{Autocorrelation Test}




\section{Journal of Management and Leadership}

Vol 3, No. 2 November 2020

Autocorrelation is examined by Durbin-Watson and check the correlation between variable. According (Ghozali, 2011) it can be said free autocorrelation when the value of Durbin-Watson between 1.715 to 2.22848 .

Table 4. Durbin-Watson result

\begin{tabular}{|l|r|}
\hline \multirow{2}{*}{ Model Summary } \\
Model & \multicolumn{1}{|c|}{ Durbin-Watson } \\
\cline { 2 - 2 } 1 & 2.021 \\
\hline
\end{tabular}

This research is no autocorrelation because the value of Durbin-Watson is 2.021 which between $1.715-2.22848$.

\section{Heteroscedasticity Test}

Heteroscedasticity appear if independent variable (motivation, belief and attitudes, occupation, economics situation, personality and self-concept, and lifestyle) significant influence residual of regression result. In heteroscedasticity test, we can see by the pattern of scatterplot. It is normal distributed or homoscedasticity when the points spread and not converge in one point and if the points are tendencies to make a pattern, its means the data are not normal distributed and considered to become heteroscedasticity. By the scatterplot below, the points were spread each other and it's indicate there is no heteroscedasticity problem and the data distributed normal.

Scatterplot

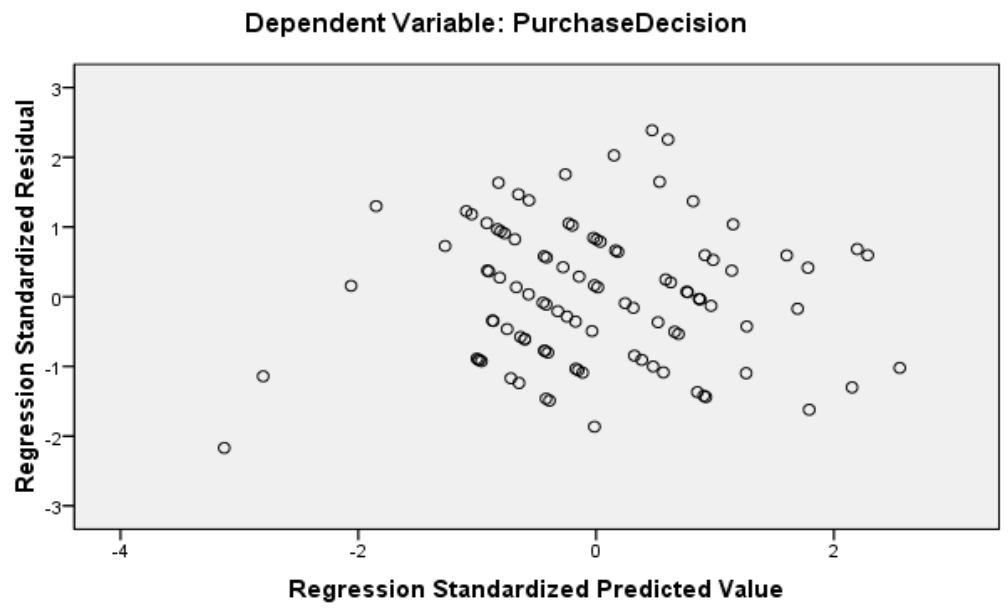

Figure 2. Heteroscedasticity Test

\section{Multiple Regression}

Table 5. Multiple Regression Test 


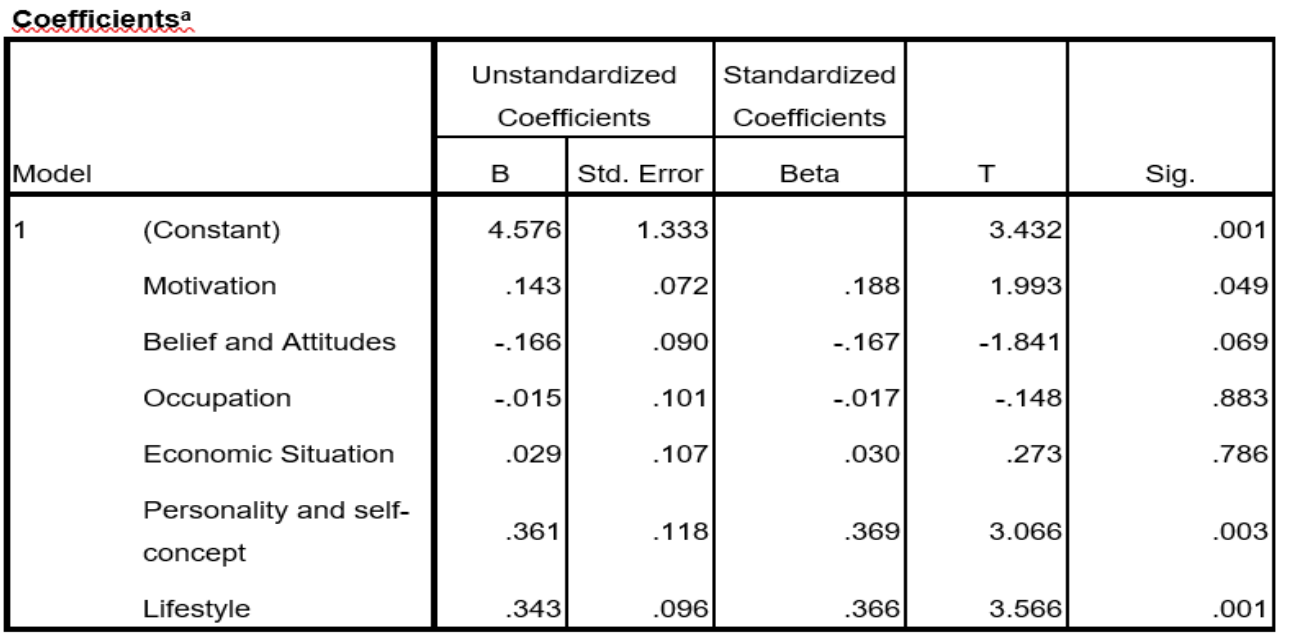

a. Dependent Variable: PurchaseRecision

Based on table above, the equation of multiple linear regression can be generated into:

\section{Purchase decision $=4.576+0.188$ Motivation -0.167 Belief and attitudes +0.369 Personality and self-concept $+\mathbf{0 . 3 6 6}$ Lifestyle}

Referring to these results, the following interpretations can be made

\section{The influence of motivation toward consumer purchase decision}

According to the result by T-test and significant level, we can conclude that motivation has partial significant influence toward consumer purchase decision of PeterSaysDenim in Bandung which Tcount is $1.993>1.984$ of Ttable and significant value $0.049<0.05$ of significant level. So, motivation has influence when consumer decided purchase PeterSaysDenim, according to Mathin Khan (2006), a person can be motivated to purchase for convenience, style prestige, or being at part with others. In this case, consumer purchase PeterSaysDenim to fulfill their need, want, purpose, satisfy, and to get achieve which PeterSaysDenim that has good quality and fashionable of design, consumer need to wearing jeans that make them confortable, good looking and feel satisfy to support their style.

\section{The influence of believe and attitudes toward consumer purchase decision}

According to the result by T-test and significant value, we can conclude that occupation has no partial significant influence toward consumer purchase decision of PeterSaysDenim which Tcount is $-1.48<1.984$ of Ttable and significant value is $0.883>$ 0.05 of significant level. It shows that when consumer purchasing PeterSaysDenim, they are not considered to their occupation. Previous research by Tamboli (2008) about Fashion Clothe Buying Behavior Danish Female Student shows that status has no significant influence toward consumer purchase decision. In this case, consumer of PeterSaysDenim is not looking so much about their status. Meanwhile, the indicators of occupation are temporal in position, physical and social-culture. In the other words, position, status, and their job have no significant influence when they decided to purchase PeterSaysDenim.

\section{The influence of occupation toward consumer purchase decision}

According to the result by T-test and significant value, we can conclude that occupation has no partial significant influence toward consumer purchase decision of 
PeterSaysDenim which Tcount is $-1.48<1.984$ of Ttable and significant value is $0.883>$ 0.05 of significant level. It shows that when consumer purchasing PeterSaysDenim, they are not considered to their occupation. Previous research by Tamboli (2008) about Fashion Clothe Buying Behavior Danish Female Student shows that status has no significant influence toward consumer purchase decision. In this case, consumer of PeterSaysDenim is not looking so much about their status. Meanwhile, the indicators of occupation are temporal in position, physical and social-culture. In the other words, position, status, and their job have no significant influence when they decided to purchase PeterSaysDenim.

\section{The influence of economic situation toward consumer purchase decision}

According to the result by T-test and significant value, which result shows that Tcount is $0.273<1.984$ of Ttable and significant value is $0.786>0.05$ of significant level. So, economic situation has no partial significant influence towards consumer purchase decision of PeterSaysDenim. In this case, consumers were still purchase PSD whether their economic good or not because consumer can purchase PeterSaysDenim from their income, saving. So, economic situation has no partial significant influence towards purchase decision because consumer refers to look the other aspect such as quality and design.

\section{The influence of personality and self-concept toward consumer purchase decision}

According to the result by $\mathrm{T}$-test and significant value, we can conclude that personality and self-concept has partial significant influence towards consumer purchase decision of PeterSaysDenim in Bandung which has Tcount is $3.066>1.984$ of Ttable and significant value is $0.003<0.05$ of significant level. The result shows that, personality and self-concept is important factor toward consumer decision, consumers were seeking their personality and self-concept when they were purchase PeterSaysDenim. It supports by Nancy Hodges (2012) that Personality and self-concept has significant influence on purchase decision which people select the fashion items based on their concept.

\section{The influence of lifestyle toward consumer purchase decision}

According to the result by T-test and significant value, we can conclude that lifestyle has partial significant influence toward consumer purchase decision of PeterSaysDenim which $\mathrm{T}_{\text {count }}$ is $3.566>1.984$ of $\mathrm{T}_{\text {table }}$ and significant value is $0.001<0.05$ of significant level. So, means that lifestyle has significant influence towards consumer purchase decision. It supports from the previous research by Stenly Winata (2006) that lifestyle has high influence towards consumer purchase decision with $68 \%$.

7. Simultaneous influence of motivation, belief and attitudes, occupation, economic situation, personality and self-concept, and lifestyle toward consumer purchase decision

The result of F-Test shows that all the independent variables (motivation, belief and attitudes, occupation, economic situation, personality and self-concept, and lifestyle) have simultaneous significant influence toward dependent variable (consumer purchase decision). The result shows that Fcompute $\neg$ is 16.083 which Ftable $\neg$ is 2.20, means that Fcompute > Ftable $\neg$ and makes reject $\mathrm{HO}$ and accept Ha. It support from the previous research by Wang Zaichen (2013) entitled influence factors of chinese purchase behavior in clothing market. So, can concluded that, there are simultaneous significant influence of motivation, belief and attitudes, occupation, economic situation, personality and selfconcept, and lifestyle toward consumer purchase decision of PeterSaysDenim in Bandung. 


\section{Coefficient Determination $\left(\mathbf{R}^{2}\right)$}

Table 6. $\mathbf{R}^{2}$ result

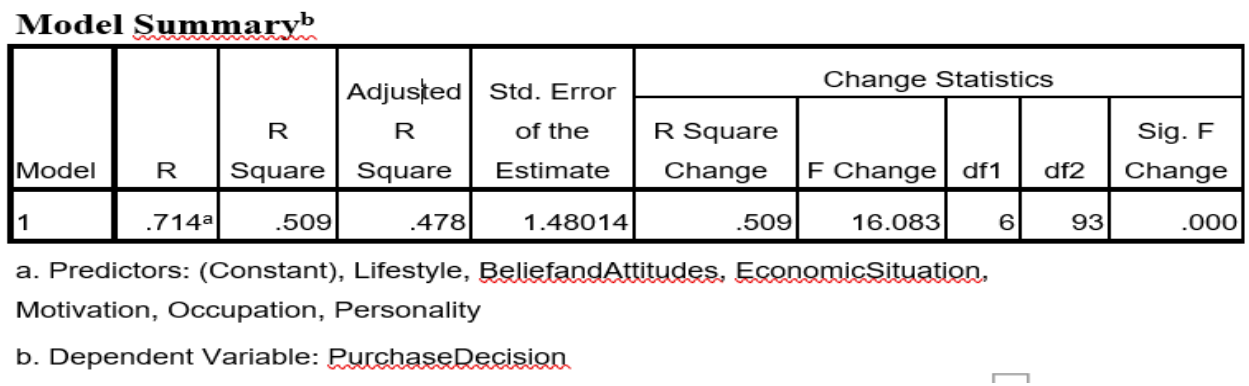

The value of coefficient determination $\left(\mathrm{R}^{2}\right)$ is 0.478 means that $47.8 \%$ changed in dependent variable (purchase decision) which it will be influenced by independent variable (motivation, belief and attitudes, occupation, economic situation, personality and selfconcept, lifestyle). Meanwhile, 0.522 or $52.2 \%$ are influenced by other variable..

\section{Conclusion}

Motivation has partial significant influence toward consumer purchase decision of PeterSaysDenim. The result show that significant value is $0.049<0.05$ and Tcount is $3.432>$ 1.984 of the Ttable, which indicates there is partial significant influence toward consumer purchase decision. If motivation is increase, consumers will be high in purchase PeterSaysDenim because more consumers have motivates to fulfill their needs and satisfy it based on their wants. Therefore, the denim's demand to be higher.

Belief and attitudes has no partial significant influence toward consumer purchase decision of PeterSaysDenim. The result show that the significant value is $0.069>0.05$ and Tcount is $-1.841<1.984$ of the Ttable which indicates there is no partial significant influence towards consumer purchase decision. However, whether consumer like Rock and Metal music or not, it will not influenced towards consumer purchase decision.

Occupation has no partial significant influence toward consumer purchase decision of PeterSaysDenim. Result shows that the significant value is $0.883>0.05$ and Tcount is -0.148 $<1.984$ of the Ttable which indicates there is no partial significant influence toward consumer purchase decision.

Economic situation has no partial significant influence toward consumer purchase decision of PeterSaysDenim. The result show that significant value is $0.786>0.05$ and $\mathrm{T}_{\text {count }}$ is $0.273<1.984$ of the Ttable which indicates that economic doesn't change consumer to purchase PeterSaysDenim.

Personality and self-concept has partial significant influence toward consumer purchase decision of PeterSaysDenim. The result show that the significant value is $0.003<0.05$ and Tcount is $3.066>1.984$ of the $T_{\text {table }}$ which indicates that consumer seeking to the character and concept of them because every consumer has their own personality and self-concept in fashion style.

Lifestyle has partial significant influence toward consumer purchase decision of PeterSaysDenim. The result show that the significant value is $0.001<0.05$ and $\mathrm{T}_{\text {count }}$ is 3.566 $>1.984$ of the $\mathrm{T}_{\text {table. }}$ Motivation, belief and attitudes, occupation, economic situation, personality and self-concept, and lifestyle have simultaneous significant influence toward consumer purchase decision of PeterSaysDenim. The result shows that $\mathrm{F}_{\text {count }}$ is $16.083>2.20$ of the $\mathrm{F}_{\text {table. }}$ 


\section{References}

Belk, Russell W. (1988). Possessions and Extended Self. Journal of Consumer Research.

Carducci, B. J. (2009). The Psychology of Personality: Viewpoints, Research, and Applications. United Stated of America: Wiley Blackwell.

Ferrell, O. C., \& Hartline, M. (2008). Marketing Strategy. Thamson Learning.

Firmansyah, P. (2014). Peter Says Denim ( Company Profile). Bandung: Peter Says Denim.

Ghozali. (2011). Aplikasi analisis multivariate dengan program SPSS Edisi 5. Semarang: Semarang Badan Penerbit Universitas Diponegoro.

Gianie Abdu, Purwanto. (2013). Analysis of Consumer Behavior Affecting Consumer Willingness to Buy in 7-Eleven Convenience Store. http://www.hrpub.org.

Hamm \& Cundiff. (1969). Self Actualiation and Product Perception. Journal of Marketing Research.

Kielhofner, G. (2002). Model of Human Occupation. Lippincott Williams \& Wilkins.

Lantos, G. P. (2011). Consumer Behavior in Action. New York: M.E. Sharpe, Inc.

Mathin Khan. (2006). Consumer Behavior and Advertising Management. New Delhi: New Age International.

Philiph Kotler \& Amstrong. (2008). Principle of Marketing. Pearson Education South Asia.

Richard, T. (2014). Professional Marketing and Advertising Essays and Assignments. Tony Ma.

Shah, A. (2010). Factor Affecting Consumer Behavior.Journal article.

Stenly Winata \& David. (2006). Analisis Pengaruh Situasi Pembelian dan Gaya Hidup terhadap Keputusan Pembelian Celana Jeans di Matahari Departement Store Surabaya: Studi Kasus pada Matahari Departement Store Plaza Tunjungan. Petra University Journal.

Tamboli, Sajid M. (2008). Fashion Clothe Buying Behavior Danish Female Student. Journal student portal master thesis

Widarjono, A. (2010). Analisis Statistik Multivariat Terapan 1st edition. Yogjakarta: Unit penerbit dan percetakan: Sekolah Tinggi Ilmu Management YKPN.

Wang, Zaichen. (2013). Influential Factors of Chineese Purchaser Behavior In Clothing Marketing.Journal of theseus

Yustisia, E. (2008). Analisis Faktor- Faktor Yang Mempengaruhi Kinerja Pegawai Kantor Pemeriksaan dan Penyidikan Pajak Banda Aceh. Journal of Magister Management. 